\title{
The Importance of Linguistics for Teachers in English Language Teaching
}

\author{
Sholihatul Hamidah Daulay \\ Universitas Islam Negeri Sumatera Utara \\ sholihatulhamidah@uinsu.ac.id \\ Muhammad Dalimunte \\ Universitas Islam Negeri Sumatera Utara \\ muhammaddalimunte@uinsu.ac.id \\ Diah Widya Ningrum \\ Universitas Islam Negeri Sumatera Utara \\ diahwidyaningrum@uinsu.ac.id
}

\begin{abstract}
This writing aims to determine the function of Linguistics in English Language Teaching. It will discuss how important linguistics in English language teaching is. It uses the literature review method or called library research. In collecting the data, it uses the descriptive method and comparison method. From the finding, it can be concluded that linguistics pays attention to its function in teaching. Linguistics and language teaching are closely related to each other. This is because language teaching goes hand in hand with language growth. How is it possible that a language teacher can practice language skills if he does not master linguistics itself, how can he train writing skills if he does not master spelling, morphology, syntax, semantics, and lexicology? In addition, as a language teacher, he not only has to practice language skills but also has to explain the rules of the language correctly.
\end{abstract}

Keywords: English Language Teaching, English teachers, linguistics. 


\section{INTRODUCTION}

Linguistics is the scientific study of language and there are several materials studied in linguistics that are called linguistics scope. In general, linguistics is the search for knowledge that humans unconsciously have about language, an understanding of the structure of language, and knowledge of how various languages differ from one another. In various general dictionaries, linguistics is defined as the science of language or the scientific study of language (Chaer 2012:2, Langacker, 1973:35, Lyons 1975:1, Martinet, 1987:19, Matthews 1997:59, Pit Corder 1973:82, Widdowson 1985:15)

The study of linguistics has undergone three stages of development, namely from the first stage called the speculation stage, the second stage is called the observation and classification stage, and the third stage is called the theory formulation stage (Chaer 2003:332). In the history of its development, linguistics is filled with various schools and understandings which from the outside seem very complicated, contradictory, and confusing, especially for beginners (Chaer, 2003: 332).

Linguistics is divided into several sub-disciplines of linguistics. Based on the object of study, language in general or a particular language is divided into two, namely General Linguistics and Special Linguistics. Based on the object of study, language at a certain period or language throughout the ages is divided into four, namely Synchronic Linguistics, Descriptive Linguistics, Comparative Historical Linguistics, and Contrastive Linguistics. Based on the object of the study, whether the internal structure of language or language concerning factors outside the language is divided into Micro Linguistics and Macro Linguistics (Soeparno, 1995:17-18).

Based on the purpose, whether a linguistic inquiry is to formulate a theory or to be applied, it is divided into Theoretical Linguistics and Applied Linguistics. Based on its relationship with factors outside of language, it is divided into Dialectology, Sociolinguistics, Anthropology, Stylistics, and Philology. Based on the flow or theory used in language investigation, it can be divided into Traditional Linguistics, Structural Linguistics, Transformational Linguistics, Semantic Linguistics, Rational Linguistics, and Systemic Linguistics.

In language teaching, it cannot be separated from the things that have been mentioned above. When a language teacher teaches about the language itself, it requires science to help create an effective teaching and learning process. He/she must understand either the 
language that is commonly used (everyday language) or a foreign language. Then, one of the sciences most related to language teaching is linguistics.

Several studies have been done before. Franscy (2015) focused on the use of linguistics in the research. Meanwhile, Aziz Thaba (2014) focused on the role of linguistics not only to the language teacher but also to the experts of language or linguists. However, the discussion in this writing only focuses on the importance of linguistics for teachers specifically in English language teaching. The researcher will discuss the use of linguistics for English language teachers especially.

\section{THEORETICAL FRAMEWORK}

The word linguistics comes from the Latin "lingua" which defines language. Kridalaksana (1993) stated in his linguistic dictionary, the word linguistics is meant as the science of language or scientific language investigation. The same definition was put forward by Tarigan (1986), which is a set of knowledge obtained by applying the scientific method to the phenomenon of language. As a scientific study of language, linguistics does not distinguish between one language and another (Hasanan, 1984).

In essence, linguistics is identical to language teaching. It must be admitted that there is a very close relationship between the two. There are two different opinions among linguists. Some argue that Language Science as a science must be autonomous and independent (Parera 1991:20, Suriasumantri 2009:20). Linguistics is pure science that seeks to study and analyze its object under the linguistic theory it adheres to without regard to its use and function. There is also the opinion of Linguistics experts who state that in addition to being a pure science, Linguistics must also think about ways to apply it in everyday life for the benefit of humans, among which the important thing is Language Teaching.

Language teaching activities are efforts that result in students being able to learn languages effectively and efficiently. The linguistic theory itself is separated to allow a language teacher to gain knowledge of how to apply these linguistic theories in language knowledge because we know that a person who is proficient in a language does not guarantee that he or she is someone who can teach language to others. Teaching speaking in the classroom is always intended to result in communicative activities that allow for a personal relationship to be formed grow both inside and between learners and lecturer. We dubbed it a communicative activity (Gusmuliana, et. al, 
2020). Likewise, language teaching is a practical and pragmatic science. The main purpose of language teaching is to achieve the results of language teaching, students master the target language as a means of communication well (Basiran in Miftah 2010).

For a teacher, speaking and understanding a language is one thing, and another is how to achieve the technical knowledge needed to understand and explain the language system, its phonemes, morphemes, words, sentences, and discourse structures. Each has a different view of language, and it is wise for the language teacher to pay attention to these differences to obtain a unified picture of the object. There are two questions in language teaching that need to be solved, namely: what to teach and how to teach it. These are content and method issues, outcomes design issues, and process design issues. The method of teaching language and its teaching itself ultimately depends on what the language is according to the views of the teacher and the compilers of the method (Mackey 1965:139). Therefore, linguistics plays an important role in language teaching which aims to make students able to communicate skillfully in various communication contexts.

\section{RESEARCH METHODOLOGY}

This study was conducted in the form of qualitative research, by using library research. Library research is research conducted using literature (library), either in the form of books, notes, or reports on the results of previous research (Sugiyono, 2016). In this case, the researcher used the step-by-step process to gather information from some articles, journals that related to the variables researched namely linguistics, language teachers, and language teaching. There are 6 articles or journals related to linguistics, and there are 7 articles or journals related to language teaching.

After collecting the data, the researcher tried to understand and interpret it into a concept that can support the study. The data source of this study is from the sources related to the topic. In analyzing the data, there are 2 kinds of methods, namely;

a. The descriptive method is a method used to describe and interpret what exists, opinions that are growing, ongoing processes, consequences or effects that occur, or trends that develop.

b. A comparative method is a method used to deliver a comparison among the theories or experts' opinions found in this study. (Sumanto, 2014). 


\section{RESULTS \& DISCUSSION Results}

The following were some articles related to both linguistics and language teaching; 1. International Journal of English Linguistics, Role of Applied Linguistics in the Teaching of English in Saudi Arabia (Khan, 2011) 2. Middle East Journal of Scientific Research, Applied linguistics and English language teaching (Khansir, 2013), 3. Language Awareness, linguistics in TESOL teacher education (LaFond \& Dogancay-Aktuna, 2009), 4. Language and Education, Becoming an English language teacher: linguistic knowledge, anxieties and the shifting sense of identity (Giovanelli, 2015), 5. Language Learning Journal, Teaching linguistics to low-level English language users in a teacher education program: an action research study (Banegas, 2020), 6. Asian Englishes, Positioning ELT in applied linguistics in Japan: A diachronic approach (Oda, 2021).

Based on some articles collected by the researchers, Lafond (2009) said that linguistics is very needed in English language teaching because this helps teachers to explain the English components and structures to the students. Every language has a system or linguistic rules that can be learned in micro linguistics terms namely phonology, morphology. syntax, and semantics studies. However, English language teaching should be incorporated with other fields (macro linguistics) such as psychology, education, cognitive science, music, anthropology, ethnology, language acquisition, sociology, bilingualism, and language teaching too.

The function of linguistics in teaching is mostly called applied linguistics and this covers research into phonetics, phonology, morphology, syntax, semantics, and occasionally includes the other titles such as psycholinguistics and sociolinguistics which concentrate on language acquisition and situation theory, respectively. In language teaching, linguistic fields such as theoretical linguistics, sociolinguistics, and psycholinguistics cannot be separated because all these disciplines make useful contributions in completing a language teaching and learning program.

In addition, Khan Intakhab Alam (2011) stated that nowadays the English teachers also used a comparative study as a means of teaching the target language. In analyzing the comparison, the English teachers need linguistics, for example, error analysis. Error analysis itself is one type of linguistics analysis that focused on analyzing the learners' mistakes. 
Furthermore, Khansir (2013) said there is a connection between these fields and language teaching. Linguistics has long been used by language teachers, who differ in their use of traditional linguistics which is full of prescriptive and normative statements, while modern linguistics is also structural and descriptive. For teachers who use an old grammar book to teach pronunciation, grammar or semantics use linguistic knowledge, namely traditional linguistics. Aspects of phonetics, phonology, morphology, syntax, and semantics are useful in teaching a language. The theoretical basis of a language is that a linguistic description will describe the language; structure and function of the language.

The contribution of linguistics to language teaching is indirect. Therefore, the field of linguistics and language teaching is autonomous and becomes its field of expertise. However, that does not mean that they do not need one another, because inevitably they require linguistic elements, namely there are many related theories of linguistics, which can be implemented in language learning and teaching. Linguistics only contributes indirectly in the form of materials.

\section{Discussion}

Teaching English as a foreign language involves a lot of knowledge and strategies. Nowadays, an English teacher is expected to know the students and teaching objectives, the subject matter, some teaching methods, and broad knowledge generally. Furthermore, an English teacher must have a strong motivation in doing his job to be a good model for the students. There are many uses of linguistics in language teaching. Six uses of linguistics in language teaching (Roulet 1975: 65-75):

1. The linguistic theory provides information about the structure and function of the language system in general to language teachers. It plays an important role in determining the objectives, content, and approach of language teaching.

2. The linguistic theory also provides an intermediate language to the teacher. This is the universality of forms such as the different types of formulas in generative transformation grammar (deletion formulas, transformation formulas, and so on). All of these things can be used by teachers in language teaching.

3. Either directly or indirectly, the linguistic theory of language acquisition affects the process of language teaching, more so how language is taught. 
4. A language description will make the teacher aware of the structure of the language to be taught, and thereby improve the quality of linguistic content in language teaching.

5. The description of language also gives the teacher knowledge of elemental units such as phonemes, morphemes, tagmemes, and so on. And also provides a list of structures or a formula system for a language that can be used in its teaching.

6. A language description provides a sequential system of formulas. It can be used to shape teaching materials. Sometimes the sequence does not need to be followed neatly.

Language teaching activities are pedagogic, pedagogical grammar is the grammar that contains language teaching and learning activities written per and for the language teaching and learning process. Informally, information about the success of a particular approach or procedure in language teaching is always available. The classroom can be considered the most accessible laboratory of all for research. Since the priority of the class is whatever is in the interest of the student's education, there is a limit to what can be achieved employing language learning research. Some continue to advocate that the teacher's role in what is often called action research and linguistics can contribute both in helping teachers to carry out such research and in efforts to introduce a stronger empirical basis for evaluation of learning and effectiveness in language teaching and learning.

The results of academic discussion and research results that have linguistic theoretical weight are transferred into postulates that guide the use of correct and good language through language education activities. If we consider linguistics and teaching as two poles, then between the two poles it is necessary to have a connector that can serve both of them best. This means of service is a new discipline called applied linguistics.

Ramelan further stated that if structural linguists believe in the contribution of linguistics to language teaching, then transformational linguists never claim to be. According to the latter, linguistics is an autonomous science, which tries to study language as a means of communication used by humans without considering the possibility that their theories about language can be applied to language teaching. This may not be separated from the attitude of Chomsky himself (a transformational figure), he even stated in a conference of language teachers that a linguist never intends to concern himself with the problems of language teaching. 
However, many transformationalists believe that the creative aspects of language that a person has (one review of this school) can be applied to language teaching, for example by training students to create and produce sentences in the language they are learning. While structural linguists agree on the role of linguistics in language teaching, it is also inseparable from Bloomfield's attitude. Besides being a linguist, he is also an expert in language teaching.

This is shown by his great concern for the teaching of modern languages. He strongly criticized the use of the grammar-translation method. According to him, the main goal of teaching foreign languages must be based on oral mastery of the language. The application of teaching methods will not run effectively and efficiently as an introductory medium for teaching materials if the application is not based on adequate knowledge of the method. So that the method may become an obstacle to the course of the teaching process, not a component that supports the achievement of goals if the application is not right. Therefore, it is very important to properly and correctly understand the characteristics of a method.

\section{CONCLUSION}

Linguistics is the science of language or the scientific study of language. Apart from being a pure science that examines and analyzes its object, linguistics also pays attention to its function in teaching. Linguistics and language teaching are closely related to each other. This is because language teaching goes hand in hand with language growth. How is it possible that a language teacher can practice language skills if he does not master linguistics itself, how can he train writing skills if he does not master spelling, morphology, syntax, semantics, and lexicology? In addition, as a language teacher, he not only has to practice language skills but also has to explain the rules of the language correctly. The usefulness of linguistics in teaching was also emphasized by Robert Lado who said that in language teaching, teachers who teach must know the linguistic elements and facts of students' mother tongues so that teachers can find out students' problems in learning the students' target language.

\section{REFERENCES}

Abidah, A., Nurul H, H., Simamora, R., Fehabutar, D., \& Mutakinati, L. (2020). The Impact of Covid-19 to Indonesian Education and Its 
Relation to the Philosophy of "Merdeka Learning." Studies in Philosophy of Science and Education.

Achugar, Mariana., Mary Schleppegrell, Teresa Oteiza. 2007. Engaging

Teachers in Language Analysis: A functional linguistics approach to reflective literacy. English Teaching: Practice and Critique, Vol. 6.

No. 2. Pp. 8-24. ISSN 11758708.

Banegas, D. L. (2020). Teaching linguistics to low-level English language users in a teacher education program: an action research study. Language Learning Journal, 48(2), 148-161. https://doi.org/10.1080/09571736.2017.1370604.

Chaer, Abdul. 2012. Linguistik Umum. Rineka Cipta: Jakarta.

Crystal, David. 1987. The Cambridge Encyclopedia of Language. Cambridge: Cambridge University Press. Madya,

Dardjowidjojo, Soenjono. 2003. Teaching, Learning, and Acquisition of Foreign Languages. Jakarta: Obor Foundation.

Giovanelli, M. (2015). Becoming an English language teacher: linguistic knowledge, anxieties and the shifting sense of identity. Language and Education, 29(5), 416-429. https://doi.org/10.1080/09500782.2015.1031677

Gusmuliana, P., Apriani, E., \& Syafryadin, S. (2021). Improving Students Speaking Motivation by Using Role Play Technique at Institute Islamic in Indonesia.

Hoffman, SJ (2010). Teaching the Humanities Online: A Practical Guide to the Virtual Classroom: A Practical Guide to the Virtual Classroom. Routledge.

Johnson, E. B. (2002). Contextual Teaching and Learning. California: Corwin Press, INC.

Giovanelli, M. (2015). Becoming an English language teacher: linguistic knowledge, anxieties and the shifting sense of identity. Language and Education, 29(5), 416-429. https://doi.org/10.1080/09500782.2015.1031677

Khan, I. A. (2011). Role of Applied Linguistics in the Teaching of English in Saudi Arabia. International Journal of English Linguistics, 1(1). https://doi.org/10.5539/ijel.v1n1p105

Khansir, A. A. (2013). Applied linguistics and English language teaching. Middle East Journal of Scientific Research, 15(8), 1140-1146. https://doi.org/10.5829/idosi.mejsr.2013.15.8.11238

LaFond, L., \& Dogancay-Aktuna, S. (2009). Teacher perspectives on linguistics in TESOL teacher education. Language Awareness, 18(34), 345-365. https://doi.org/10.1080/09658410903197348

Oda, M. (2021). Positioning ELT in applied linguistics in Japan: A 
diachronic approach. Asian Englishes, 23(1), 79-89. https://doi.org/10.1080/13488678.2020.1867952

Parera, Jos Daniel. 1986. Educational Linguistics: Approaches, Concepts, and Theory of Language Teaching. Jakarta: Erlangga Publisher.

Scheg, AG (2014). Reforming Teacher Education for Online Pedagogy Development. IGI Global.

Sevimel-Sahin, Aylin. (2020). A Survey on the Intercultural Communicative Competence of ELT Undergraduate Students. EJAL Eurasian Journal of Applied Linguistics.

Sifakis, Nicos C. (2018). Elf-Awareness In Elt: Bringing Together Theory And Practice. JELF Colloquium 2018; 7 (1): 155 - 209.

Soeparno. (2002). Dasar-dasar Linguistik Umum. Yogyakarta: PT Tiara Wacana.

Sugiyono, 2016. Metode Penelitian Kuantitatif Kualitatif dan R\&D. Bandung: Alfabeta.

Sumanto, 2014. Teori dan Metode Penelitian, CAPS (Center of Academic Publishing Service) Yogyakarta.

Suwarsih. 2013. Language Teaching Methodology: Pre-Method to Post-Method Era. Yogyakarta: UNY Press.

Zhang, Xiaodong (2017). A Critical Review of Literature on English Language Teaching Textbook Evaluation: What systemic functional linguistics can offer. Journal of Language and Cultural Education 2017, 5 (1), ISSN 1339-4584.

Widdowson, H. G. 1985. Language Purpose and Language Use. Oxford: Oxford University Press. 